\title{
Pelatihan Cedera Massage Nasional Tingkat 1
}

\author{
${ }^{1}$ Hilmainur Syampurma, \\ ${ }^{1}$ jurusan Pendidikan Olahraga,Program Studi Pendidikan Jasmani Keshatan dan Rekreasi \\ Fakultas Ilmu Keolahragaan, Universitas Negeri Padang, Indonesia \\ Email: hilmainursyam@ fik.unp.ac.id ${ }^{1}$, \\ Diterima:13 Mei 2020; Revisi: 27 Mei 2020; Disetujui 12 Juni 2020
}

\begin{abstract}
Nowadays, the development of sports has been greatly expanded rapidly. There are various sports branches that give birth to the seeds of athletes. Not even the denied, appears very professional athletes in his sports branch. The strong events followed by the athlete, forcing the athlete to practice hard. Sometimes mistakes in carrying out physical activities in exercising/exercise can cause unwanted things such as sports injuries to it is necessary for massage workers (Maseur) who have a professional knowledge and have a national certificate. Injury training massage will be very beneficial to deepen or expand the ability of the trainees provide service/services injury massage in the form of massage. In addition, with the certificate owned can provide the job field for the trainees in the field of training/injury services. The approach method is offered in solving the problem in the form of lectures, discussions, demonstrations/practices, mentoring and evaluation. The results obtained from the activities of this community devotion are the trainees get a deeper knowledge about the massage injury so that it is expected to prevent and minimize the mistakes that occur in the field, the trainees who are assigned independently, immediately get the opportunity to be a massage in their place of practice and even have been handling national football clubs with professionals and participants experienced an increase in the number of patients they provide palayanan/injuries massage services. So that the participants have a professional extra income.
\end{abstract}

Keywords: Injury Massage, National Level

\begin{abstract}
Abstrak
Masa sekarang, perkembangan olahraga sudah sangat berkembang dengan pesat. Muncul berbagai macam cabang olahraga yang melahirkan bibit-bibit atlit. Bahkan tidak dipungkuri, muncul atlit-atlit yang sangat profesional di cabang olahraganya. Padatnya eventevent yang diikuti oleh atlit, memaksa atlit untuk berlatih dengan keras. Kadang-kadang kesalahan dalam melakukan aktifitas fisik dalam berolahraga/latihan dapat menyebabkan terjadinya hal-hal yang tidak diinginkan salah satunya seperti cedera olahraga untuk itu sangat diperlukan tenaga-tenaga massage (Maseur) yang profesional yang telah memiliki pengetahuan dan bersetifikat secara nasional. pelatihan cedera massage akan sangat bermanfaat untuk memperdalam atau memperluas kemampuan para peserta pelatihan memberikan layanan/jasa cidera massage dalam bentuk pemijatan. Selain itu dengan adanya sertifikat yang dimiliki dapat memberikan lapangan pekerjaan bagi para peserta pelatihan khsusnya dalam bidang pemberian palayanan/jasa cedera massage. Metode pendekatan yang ditawarkan dalam pemecahan permasalahan berupa ceramah, diskusi, demonstrasi/praktek, pendampingan serta evaluasi. Hasil yang diperoleh dari kegiatan pengabdian masyarakat ini yaitu Para peserta pelatihan
\end{abstract}


mendapat pengetahuan yang lebih mendalam tentang cedera massage sehingga diharapkan dapat mencegah dan meminimalisir kesalahan-kesalahan yang terjadi di lapangan, para peserta pelatihan yang ditugaskan secara mandiri, langsung mendapatkan kesempatan menjadi tenaga massage di tempat mereka praktek dan bahkan sudah menangani klub-klub sepak bola nasional dengan profesional dan para peserta mengalami peningkatan jumlah pasien yang mereka berikan palayanan/jasa cedera massage. Sehingga para peserta memiliki penghasilan tambahan yang profesional.

Keywords: Cedera Massage, Level Nasional

\section{ANALISIS SITUASI}

Seiring dengan perkembangan zaman dan kebutuhan hidup yang terus meningkat, manusia cenderung berprilaku materialistis dan sekaligus instan; revolusi industry telah mengubah wajah perilaku manusia, dimana sebelumnya eksistensi manusia akan diukur melalui aktivitas fisik yang dinamis, tetapi dengan kemajuan akibat revolusi industry di atas, manusia cenderung menjauhinya dengan alasan efisiensi dan produktivitas. Mind set seperti di atas bukan berarti salah, tetapi kalau semuanya berlindung dibalik alasan seperti itu, maka manusia secara perlahan tetapi pasti sedang menggali kuburannya sendiri. Hipokinetik merupakan dampak nyata dari kemajuan industri tersebut, fenomena ini mengakibatkan manusia menjadi kurang gerak yang berdampak kepada berbagai macam penyakit akibat kurang gerak seperti diabetes, hipertensi, jantung koroner dan lain sebagainya. Namun, penyakit-penyakit ini dapat dihindari jika kita gemar untuk melakukan aktivitas olahraga.

Olahraga yang teratur akan memberikan dampak positif pada tubuh. Tak cuma mengecilkan lingkar pinggang dan paha, tapi lebih dari itu, olahraga berperan penting mengontrol kesehatan tubuh. Tanpa bergerak atau beraktivitas, tubuh manusia akan kacau balau. Denyut jantung melemah, distribusi oksigen--yang berfungsi menjaga kelenturan otot-terganggu. Tidak aneh jika seluruh tubuh mendadak pegal-pegal dan kaku. Apalagi di masa sekarang, perkembangan olahraga sudah sangat berkembang dengan pesat. Muncul berbagai macam cabang olahraga yang melahirkan bibit-bibit atlit. Bahkan tidak dipungkuri, muncul atlit-atlit yang sangat profesional di cabang olahraganya. Padatnya event-event yang diikuti oleh atlit, memaksa atlit untuk berlatih dengan keras. Kadang-kadang kesalahan dalam melakukan aktifitas fisik dalam berolahraga/latihan dapat menyebabkan terjadinya hal-hal yang tidak diinginkan salah satunya seperti cedera olahraga.

Cedera olahraga adalah cedera yang terjadi pada sistem otot dan rangka tubuh selama olahraga akibat suatu ketidaksengajaan (kecelakaan) maupun kesalahan yang sebenarnya dapat dihindari seperti kurang pemanasan, faktor motorik, Intensitas latihan yang terlalu berat, dan tingkat stress yang tinggi. Cedera olahraga yang paling sering terjadi yaitu keseleo, cedera lutut, 


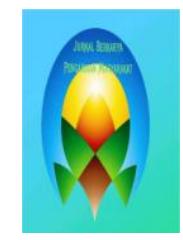

Journal Berkarya

Pengabdian kepada Masyarakat

Vol. 2, No.1, Mei, 2020,

E - ISSN 2686-6218

Link: http://jba.ppj.unp.ac.id/index.php/jba Doi: https://doi.org/ 10.24036/jba.v2i1.47

otot bengkak, cedera tendon, fraktur dan disklokasi. Kemenkes menjelaskan, sprain adalah jenis cedera yang terjadi di persendian, seperti di pergelangan bahu, tangan, dan kaki. Sprain terjadi karena adanya ketegangan atau robekan ligamen yang menyebabkan keseleo. Ligamen adalah potongan-potongan jaringan yang menghubungkan dua tulang satu sama lain dalam sendi. cedera lutut. Lutut adalah persendian yang rumit, terdiri dari empat komponen, yaitu tulang, tulang rawan, ligamen, dan tendon. Medical News Today merilis beberapa cedera lutut yang kerap terjadi, salah satunya cedera paling parah akibat olahraga, yaitu cedera ligamentum cruciate anterior (ACL) grade 3 yang mengacu pada robekan total.

Atlet yang beraktivitas dalam olahraga seperti sepak bola sering melukai ACL mereka. Tendonitis atau radang pada lutut juga dikenal sebagai patellar tendinitis. Ini adalah cedera pada tendon yang menghubungkan tempurung lutut ke tulang kering. Lliotibial band syndrome juga merupakan cedera lutut yang umum di antara pelari jarak jauh. Hal ini disebabkan ketika iliotibial band yang terletak di bagian luar lutut, bergesekan dengan bagian luar sendi lutut. Cedera terakhir yang kerap diderita dalam olahraga adalah cedera pinggang bawah. Cedera ini kerap terjadi karena adanya gerakan mendadak, berulang atau melebihi batas kekuatan otot pinggang. Menurut National Institute of Neurological Disorders and Stroke, sekitar 80 persen orang dewasa akan mengalami sakit punggung bagian bawah pada suatu saat selama hidup mereka. Sakit atau cedera otot punggung yang paling umum adalah punggung terkilir dan tegang.

Dalam olaraga profesioanal, untuk menghindari atau bahkan untuk mengatasi jika terjadi cidera dalam olahraga, maka untuk penanganan yang lebih cepat dibutuhkan tenaga maseur pada cabang olahraga tersebut. Maseur bertugas untuk memberikan pelayanan/jasa berupa pijatan-pijatan kepada atlit pada otot-otot agar tidak mudah stress dan kaku pada saat bertanding dan latihan. Pelayanan massage ini kadang diberikan sebelum pertadingan dimulai dan agar atlit lebih relaks dan bahkan pada saat pertandingan berlangsung. Untuk memberikan jasa/pelayanan ini, maka sangat diperlukan tenaga-tenaga massage (Maseur) yang profesional yang telah memiliki pengetahuan dan bersetifikat secara nasional.

Melalui Pelatihan cedera massage diharapkan menjadi sarana untuk peningkatan profesionalitas para peserta pelatihan dalam memberikan layanan/jasa dalam bentuk pemijatan dan mampu bersaing. Dengan kata lain, pelatihan cedera massage akan sangat bermanfaat untuk memperdalam atau memperluas kemampuan para peserta pelatihan memberikan layanan/jasa cidera massage dalam bentuk pemijatan. Selain itu dengan adanya sertifikat yang 


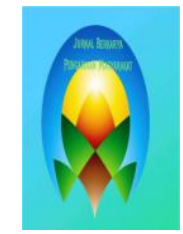

Journal Berkarya

Pengabdian kepada Masyarakat

Vol. 2, No.1, Mei, 2020,

E - ISSN 2686-6218

Link: http://jba.ppj.unp.ac.id/index.php/jba Doi: https://doi.org/ 10.24036/jba.v2i1.47

dimiliki dapat memberikan lapangan pekerjaan bagi para peserta pelatihan khsusnya dalam bidang pemberian palayanan/jasa cedera massage

\section{SOLUSI DAN TARGET}

Solusi yang dapat diberikan untuk menjawab kurangnya tenaga maseur dalam memberikan pelayanan/jasa cedera massage ini adalah dengan melakasanakan kegiatan pelatihan ini yang bertujuan untuk: "menambah dan meningkatkan keterampilan dan pengetahuan para peserta khususnya dalam bidang cedera massage"

Target yang akan dicapai dalam kegiatan pengabdian msayarakat ini adalah melahirkan tenaga-tenaga massage (maseur) yang ahli, memiliki pengetahuan dan keterampilan yang lebih mendalam tentang cedera massage, profesional dan memiliki lisensi yang dibuktikan dengan diterbitkannya sertifikat oleh tim pelaksana pengabdian masyarakat ditandatangani oleh Instansi pelaksana pengabdian beserta nara sumber.

\section{METODE PELAKSANAAN}

Dalam kegiatan Pengabdian Kepada Masyarakat ini ditawarkan berbagai pendekatan. Metode pendekatan yang ditawarkan dalam pemecahan permasalahan adalah sebagai berikut:

1). Ceramah meyampaikan materi-materi pendukung cedera massage

2). Diskusi langsung dengan khalayak sasaran tentang pengetahuan awal mereka terhadap cedera massage olahraga.

3). Pelatihan atau pembekalan pengetahuan/teori cedera massage.

4). Pelatihan/demontrasi tentang praktek teknik manipulasi cedera massage.

5). Pendampingan dan evaluasi peserta pelatihan di lapangan

\section{PELAKSANAAN KEGIATAN}

\section{Tempat dan Waktu}

Kegiatan pengabdian kepada masyarakat ini dilaksanakan pada tanggal $16-18$ November tahun 2019 bertempat di Aula Labor Fakultas ilmu keolahrgaan dengan mendatangkan nara sumber yang sudah ahli,berpengalaman luas dan sudah memiliki lisenci Internasional dan melibatkan mahasiswa Fakultas ilmu keolahrgaan sebanyak 50 orang. 


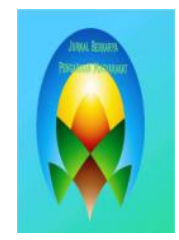

Journal Berkarya

Pengabdian kepada Masyarakat

Vol. 2, No.1, Mei, 2020,

E - ISSN 2686-6218

Link: http://jba.ppj.unp.ac.id/index.php/jba

\section{Metode Evaluasi}

Untuk mengevaluasi kegiatan digunakan metode penugasan mandiri kepada peserta pelatihan. Tugas mandiri yang diberikan adalah para peserta terjun langsung kelapangan untuk menangani berbagai macam permasalahan yang terjadi dilapangan khususnya pada kegiatankegiatan olahraga.

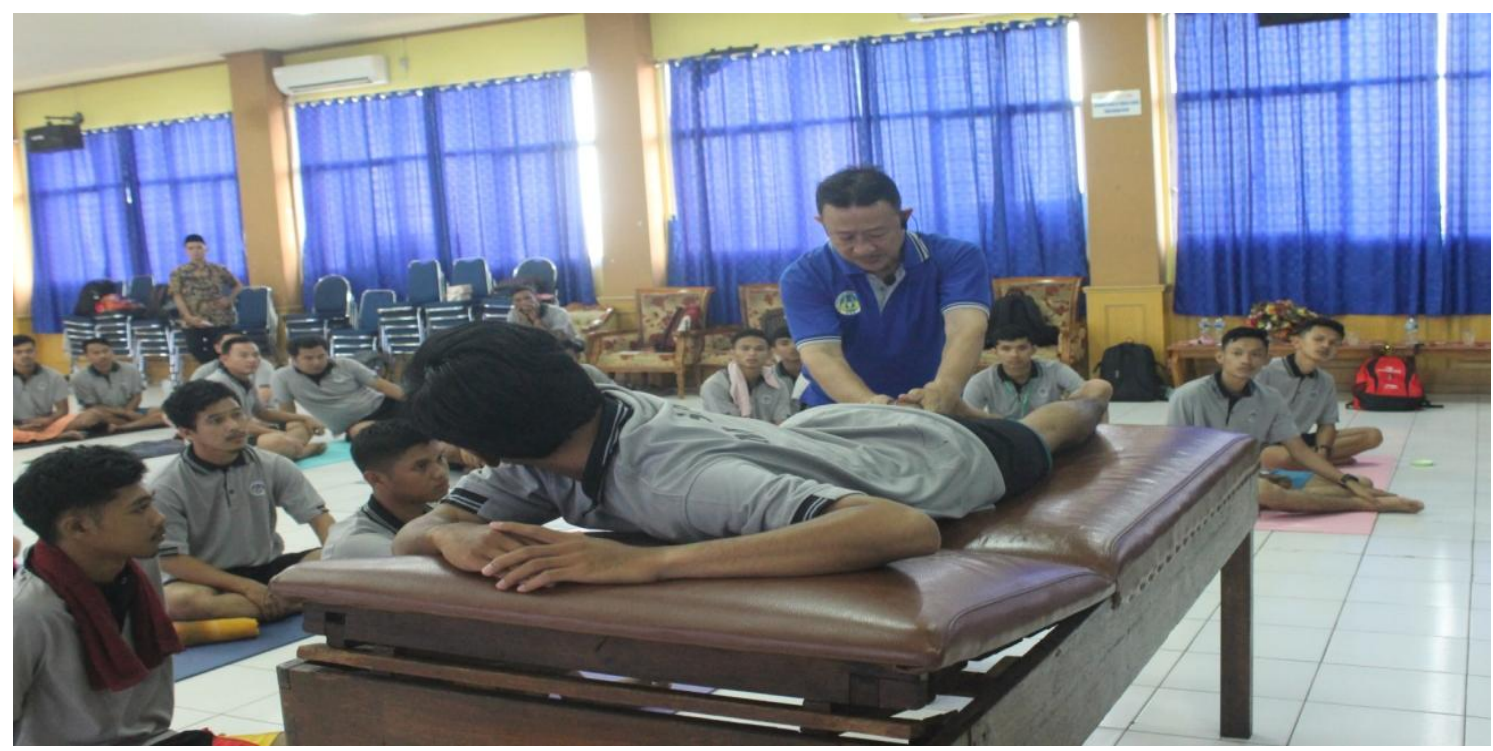

Gambar 1.

Demonstasi Praktek Cedera Massage

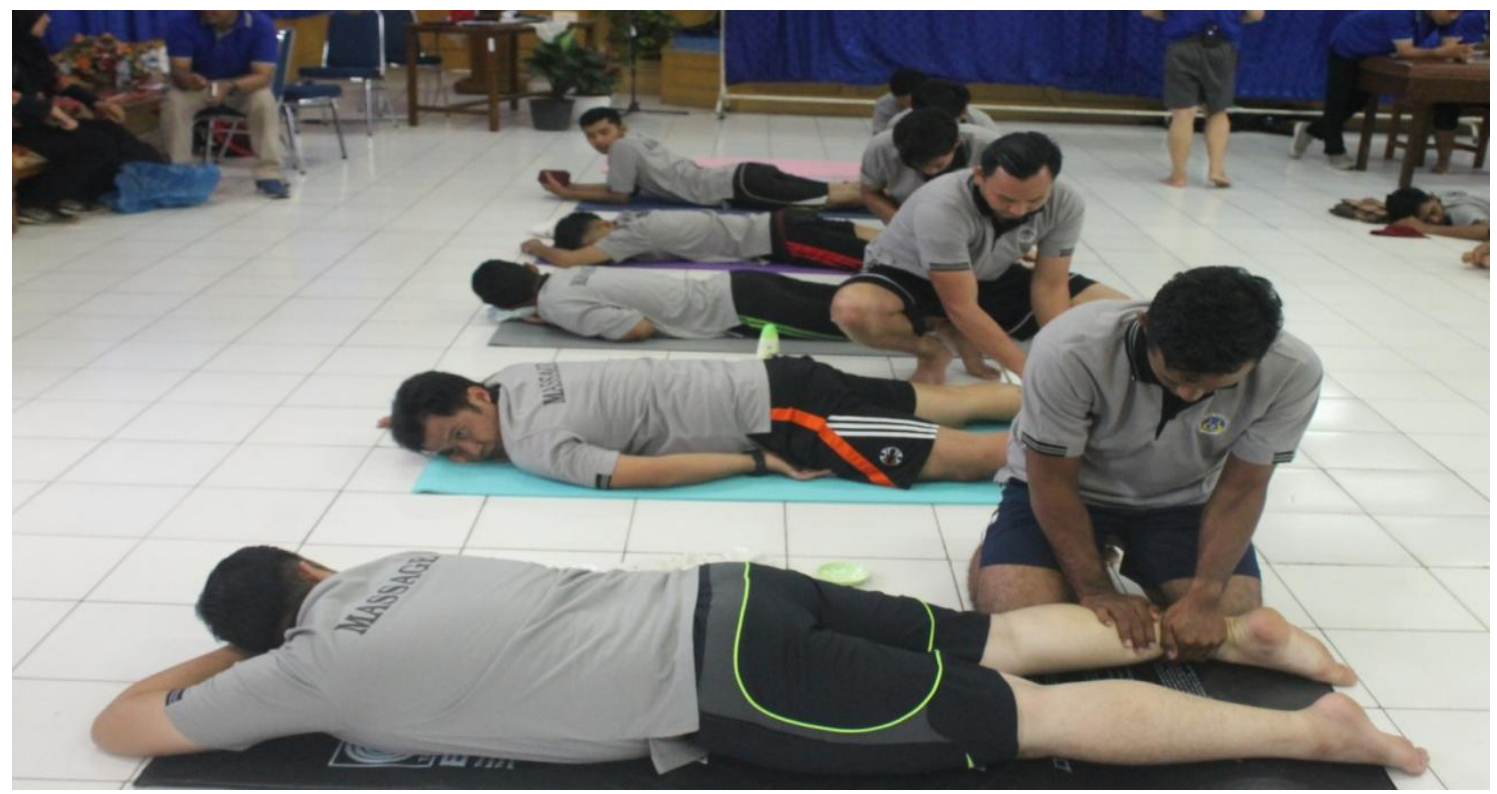

Gambar 2

Peserta Melakukan Praktek Cedera Massage

Link: http://jba.ppj.unp.ac.id/index.php/jba

Doi: https://doi.org/ 10.24036/jba.v2i1.47 


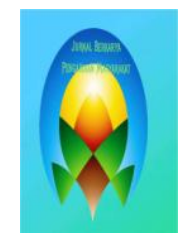

Journal Berkarya

Pengabdian kepada Masyarakat

Vol. 2, No.1, Mei, 2020,

E - ISSN 2686-6218

Link: http://jba.ppj.unp.ac.id/index.php/jba

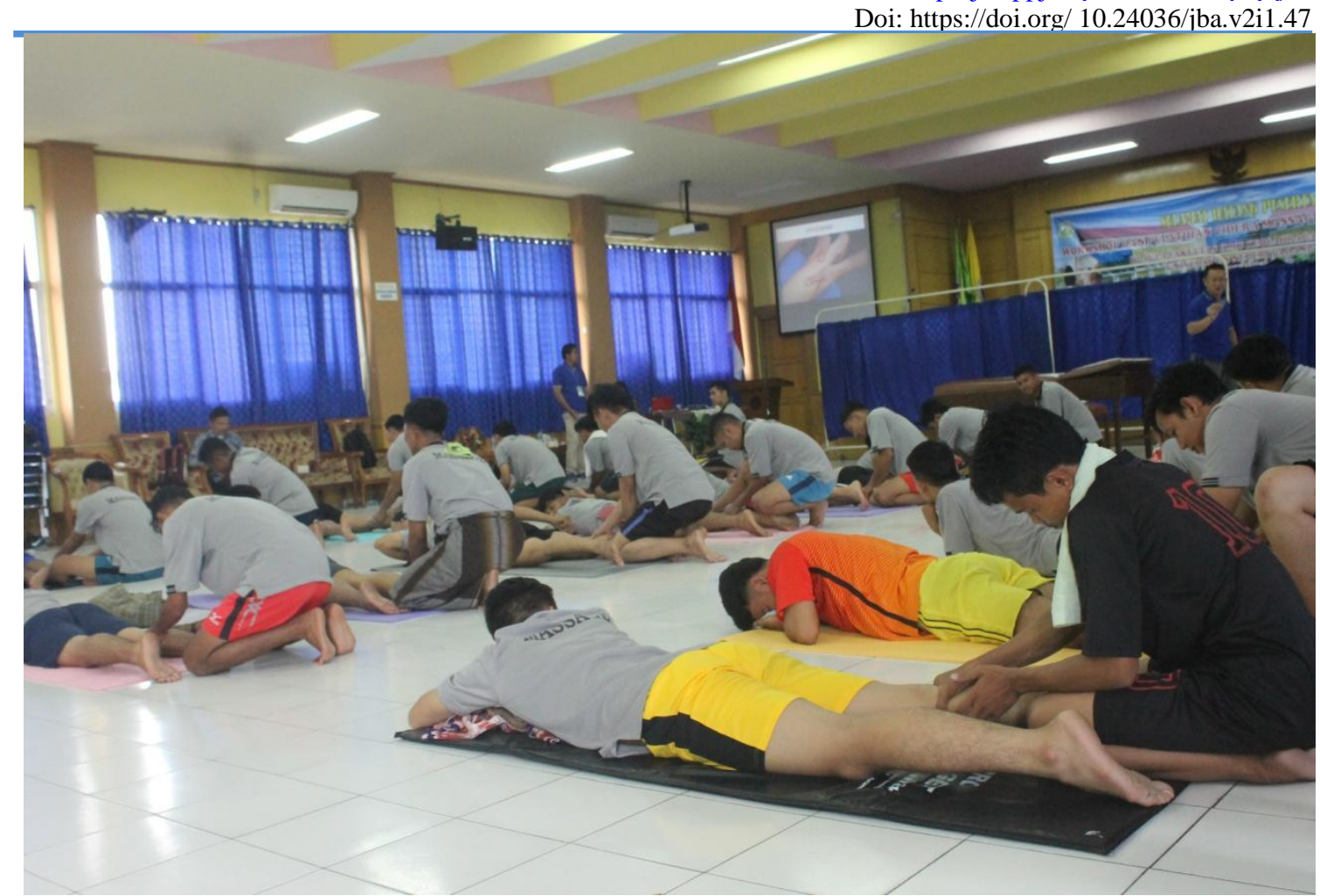

Gambar 3

Peserta Melakukan Praktek Cedera Massage

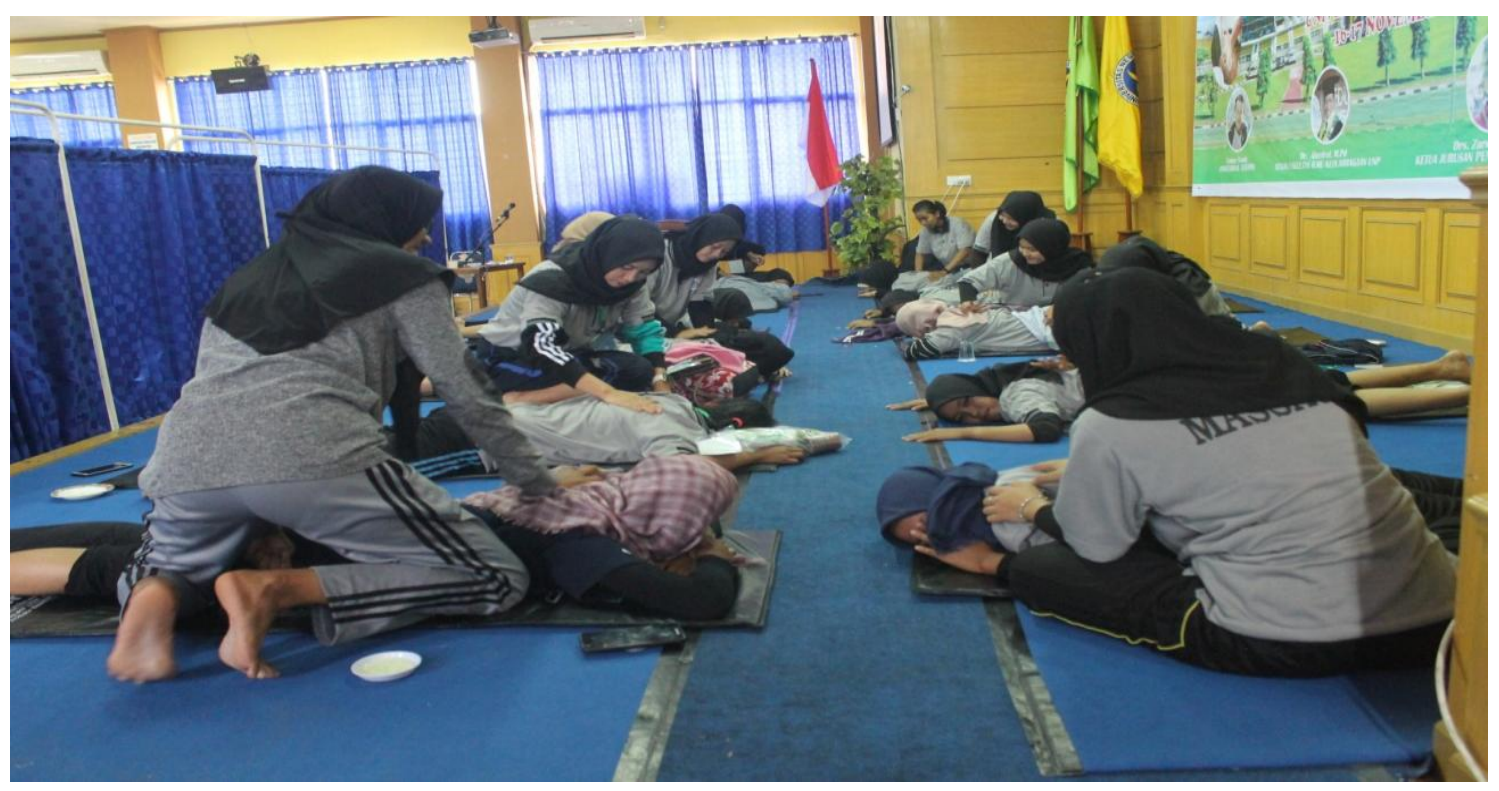

Gambar 4

Peserta Melakukan Praktek Cedera Massage

Link: http://jba.ppj.unp.ac.id/index.php/jba

Doi: https://doi.org/ 10.24036/jba.v2i1.47 


\section{Hasil}

Hasil yang diperoleh dari kegiatan Pengabdian Kepada Masayarakat yang dilaksanakan pada tanggal 16 - 18 Noveember 2020 adalah:

1. Para peserta pelatihan mendapat pengetahuan yang lebih mendalam tentang cedera massage. Pengetahuan yang diperoleh tidak hanya sekedar materi dan teori tetapi juga praktek langsung yang dicontohkan oleh nara sumber yang kemudian dipraktekan langsung oleh para peserta. Pada saat peserta melakukan praktek, nara sumber dan Tim Pengabdian Kepada Masyarakat mengawasi langsung gerakan-gerakan yang dilakukan. Jika tidak sesuai maka, nara sumber dan tim langsung memperbaiki gerakan yang salah tersebut. Sehingga praktek dan pengawasan langsung yang dilakukan, diharapkan dapat mencegah dan meminimalisir kesalahan-kesalahan yang terjadi di lapangan.

2. Para peserta pelatihan yang ditugaskan secara mandiri, memberikan respon positif dan informasi yang membanggakan,yakni pserta yang melakukan tugas mandiri dilapangan langsung mendapatkan kesempatan menjadi tenaga massage di tempat mereka praktek. Diantaranya ada yang menjadi tenaga massge di Club Sepak bola Nasional yaitu Bali United dan Semen Padang.

3. Setelah ditugaskan secara mandiri, para peserta pelatihan memberikan report yang luar biasa,yakninya para peserta mengalami peningkatan jumlah pasien yang mereka berikan palayanan/jasa cedera massage. Sehingga para peserta memiliki penghasilan tambahan yang profesional.

\section{Pembahasan}

Cedera dapat diartikan kerusakan pada bagian bagian tubuh sehingga tidak mammpu menjalankan fungsinya dengan baik hal ini bisa diakibatkan karena benturan fisik dengan orang lain atau karena kesalahan gerakan yang kita lakukan atau hal lainnya.Cedera juga dapat digolongkan dalam beberapa yang pertama ada cedera ringan yang bisa sembuh dengan cepat dengan beberapa pengobatan dan istirahat yang cukup sedangkan yang kedua adalah cedera berat dimana cedera ini memakan waktu yang lama untuk sembuh bahkan ada cedera berat yang mengakibatkan beberapa bagian tubuhnya tidak bisa berfungsi lagi secara normal (https://brainly.co.id/tugas/15935446). Cedera seperti strain dan sprain adalah cedera olahraga yang bisa langsung ditangani dengan kompres. Sering bila ada suatu kejadian cedera pada olahraga, yang dilakukan adalah pemberian massage .Namun sebelum diberikan massage, harus 

diperhatikan terlebih dahulu bentuk-bentuk dan dimana terjadinya cideranya. Kemudian dilakukan tindakan REST. $\mathrm{R}=$ Rest (istirahat), $\mathrm{I}=$ Icing (diberi Es/yang sifatnya dingin), $\mathrm{C}=$ Compresion,(dikompres/bebat),E=Elevation(elevasi)https://www.alomedika.com/komunitas/ topic/do-rice-no-harm.

Depdiknas (2005:562) dalam Kamus Besar Bahasa Indonesia (KBBI) menjelaskan bahwa, masase adalah pemijatan, pengurutan, dsb pada bagian-bagian badan untuk melancarkan peredaran darah sebagai cara pengobatan atau untuk menghilangkan rasa capai. Secara akademis, istilah pemijatan atau pijat lebih dikenal dengan istilah masase (massage). Darni (2008:i) menjelaskan bahwa: Massage merupakan istilah dalam bahasa Inggris yang kemudian diindonesiakan menjadi masase. Istilah massage (masase) diduga berasal dari: (1) bahasa Perancis yaitu masser yang berarti menggosok; (2) Arab dari kata ma'sh yang berarti menekan dengan lembut; (3) Yahudi dari kata maschesch yang berarti meraba; dan (4) Yunani dari kata massien yang berarti memijat atau melutut. Masase cedera olahraga merupakan suatu kondisi seseorang yang sedang mengalami gangguan kesehatan sebagai akibat melakukan aktivitas olahraga seperti terkilir atau kaseleo,nyeri otot, sakit kepala, kelelahan, muntah-muntah, pingsan dan sebagainya.

Cedera massage adalah merupakan suatu teknik pemijatan atau pengurutan yang bertujuan untuk memulihkan seseorang yang mengalami cedera pada saat berolahraga yang dapat merugikan kesehatannya . Menurut Bambang Wijanarko (2010:53) masase terapi cedera olahraga hanya menggunakan beberapa teknik berikut, yaitu "gerusan (friction) dan gosokan (effleurage) menggunakan ibu jari, dan dilanjutkan dengan penarikan (traksi) untuk mengembalikan sendi pada posisinya (reposisi)."

Sesuai maksud kutipan di atas dapat dijelaskan lebih lanjut bahwa: (1) Gerusan (friction) bertujuan untuk menghancurkan myogelosis atau timbunan sisa-sisa pembakaran yang terdapat pada otot dan menyebabkan pengerasan serabut otot; (2) Gosokan (effleurage) dengan menggunakan ibu jari untuk menggosok daerah tubuh yang mengalami kekakuan otot, bertujuan untuk memperlancar peredaran darah; dan (3) Tarikan (traksi) untuk menarik bagian anggota gerak tubuh yang mengalami cedera khususnya pada sendi ke posisi semula (D Darni, W Welis JURNAL STAMINA 1 (1), 415-424.

Berdasarkan teori-teori yang telah dijelaskan, bahwasanya pemberian/penanganan dengan memberikan pelayanan/jasa cedera massage pada saat ini sangat dibutuhkan sekali. Karena latihan yang berat dan kurangnya pemanasan dapat menyebabkan terjadinya cidera. Dengan adanya pelatihan cedera massage ini, telah memberikan pengetahuan dan keterampilan 


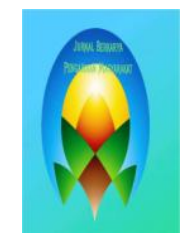

Journal Berkarya

Pengabdian kepada Masyarakat

Vol. 2, No.1, Mei, 2020,

E - ISSN 2686-6218

Link: http://jba.ppj.unp.ac.id/index.php/jba Doi: https://doi.org/ 10.24036/jba.v2i1.47

kepada peserta pelatihan. Sehingga para peserta mengetahui ilmu-ilmu tentang cedera massage.

Dengan mengetahui teori yang ada tentang cedera,jenis-jenis dan bentuk penangannannya, akan meminimalisir terjadinya keselahan. Selain itu dengan adanya pelatihan, memberikan informasi yang jelas tentang waktu-waktu yang tepat untuk pemberian pelayanan/jasa massage. Dengan pelatihan yang telah dilaksanakan ini telah membawa dampak positif kepada seluruh pesesrta. Mulai dari terciptanya lapangan kerja baru, memberikan tambahan ekonomi, dan memberikan kesempatan kepada peserta untuk mendedikasikan ilmu yang telah didapat ke lapangan dan masyarakat.

\section{KESIMPULAN}

Berdasarkan hasil dari kegiatandan evaluasi kepada peserta pada kegiatanPengabdian Kepada Masyarakat, dapat ditarik kesimpulan :

1. Para peserta pelatihan mendapat pengetahuan yang lebih mendalam tentang cedera massage. Pengetahuan yang diperoleh tidak hanya sekedar materi dan teori tetapi juga praktek langsung sehingga diharapkan dapat mencegah dan meminimalisir kesalahankesalahan yang terjadi di lapangan.

2. Para peserta pelatihan yang ditugaskan secara mandiri, langsung mendapatkan kesempatan menjadi tenaga massage di tempat mereka praktek dan bahkan sudah menangani klub-klub sepak bola nasional dengan profesional.

3. Para peserta mengalami peningkatan jumlah pasien yang mereka berikan palayanan/jasa cedera massage. Sehingga para peserta memiliki penghasilan tambahan yang profesional.

\section{PENGAKUAN}

Rasa syukur tim pengabdian ucapkan kepada Allah SWT karena berkat beliau telah memberikan rahmat dan hidayahnya, sehingga kami dapat melakukan kegiatan pengabdian ini dengan baik dan lancar. Kami juga mengucapkan terima kasih kepada semua pihak yang telah banyak membantu kami. Terima kasih kepada pimpinan Universitas Negeri Padang, Pimpinan dan civitas Fakultas Ilmu Keolahrgaan serta pihak Universitas Negeri Padang, yang telah memberikan kesempatan dan waktu yang seluas-luasnya kepada kami dalam melakukan kegiatan pengabdian. Kepada Mahasiswa. Teristimewa kepada Nara Sumber yang langsung didatangkan dari DKI Jakarta dan kepada semua peserta pelatihan yang telah bersedia dengan tenang, antusias dan penuh perhatian untuk mengikuti kegiatan pelatihan ini dari awal sampai akhir kegiatan. 


\section{DAFTAR PUSTAKA}

Bambang, Ali Setia Graha. 2004. Terapi Pemijatan Frirage. Yogyakarta, FIK UNY.

Basoeki, Sunarjo. 1973. Massage. JakartA: Direktorat Jenderal Olahraga dan Pemuda.

Darni, 2008. "Pemijatan Frirage Cara Sehat dan Dua Jari". Makalah Seminar Nasional Lokakarya Kurikulum Model Pembelajaran Kelas dan Pelatihan Massage, Padang 19-21 April.

Darni, 2009. Massage Olahraga Dasar Teori dan Manipulasi. Wineka Media, Malang.

Darni, D., \& Welis, W. (2018). Peningkatan Keterampilan MassageCedera Olahraga Guru Pendidikan Jasmani Olahraga dan Kesehatan di Kecamatan Padang Utara. JURNAL STAMINA, l(1), 415-424.

Darni, D., Deswandi, D., Wildawelis, W., \& Sepriadi, S. (2018). LATIHAN KETERAMPILAN MASASE TERPADU BAGI SISWA PENGURUS OSIS UNTUK PENINGKATAN PELAYANAN UKS DI SMP NEGERI 8 PADANG. Abdimas Dewantara, 1(2), 4555Depdikbud. 2005. Kamus Besar Bahasa Indonesia. Jakarta: Balai Pustaka

Depdikbud, 1980/1981. Spor Massage. Jakarta, Direktorat Jenderal Olahraga dan Pemuda.

Mashoed. 1980/1981. MassageOlahraga Pertolongan Pertama pada Kecelakaan dan Pendidikan Keselamatan. Jakarta: PT. New Aqua.

https://tirto.id/jenis-cedera-dalam-olahraga-dan-cara-mencegahnya-ekpc

https://www.alomedika.com/komunitas/topic/do-rice-no-harm-pada-penanggan-awal-cederaolahraga.

Ridwan, 1993. Pengantar Massage Olahraga. Padang: IKIP.

Wijanarko, Bambang, dkk. 2010. MassageTerapi Cedera Olahraga. Surakarta: Yuma Perkasa. 